\title{
PENGARUH BIAYA PRODUKSI TERHADAP HASIL PRODUKSI PADA HOME INDUSTRI SAMBEL PECEL DI KOTA MADIUN
}

\author{
Iin Purwanti \\ Mahasiswa Prodi Pendidikan Ekonomi \\ FPIPS IKIP PGRI Madiun
}

\begin{abstract}
.
This study aims to determine the production cost home industry of sambel pecel, to determine sambel pecel production in Madiun, and to know is there any effect on the cost of production yield at home industry of sambel pecel Madiun. The samples in this study using a sample that is saturated all home industries of sambel pecel in the city of Madiun, amounting to 34 Home industry of pecel. Data collection using interviews and documentation. In analyzing the data used linear regression analysis to test the hypothesis put forward in this study. The results showed that the cost of production has an influence as well as a positive relationship to yield at Home industry of sambel pecel in the city of Madiun. It is derived from the value $r_{\text {hit }} r_{\text {tab }} 0.339$ 0.982 whereas on the other hand $\operatorname{Sig}_{\text {hit }}$ value of 0.00 and $\operatorname{Sig}_{\text {pro }} \leq 0.05$. This means that $r_{\text {hit }} \geq r_{\text {tab }}(0.982 \geq 0.339)$ or $\operatorname{Sig}_{\text {hit }} \leq \operatorname{Sig}_{\text {pro }}(0.00 \leq 0.05)$, which suggested a rejection of $\mathrm{H}_{0}$ means that production costs have a relationship with industrial production at home industry of sambel pecel at Madiun city. It also obtained the $F_{h i t}$, while the value of $875.064 \mathrm{~F}_{\text {tab }} 4,149$ value on the other hand is known $\operatorname{Sig}_{\text {hit }} 0.00$ and $\operatorname{Sig}_{\text {pro }}$ 0.05. This means that the $F_{\text {hit }} \geq F_{\text {tab }}$ $(4.149 \geq 875.064) \leq \operatorname{Sig}_{\text {hit }} \leq \operatorname{Sig}_{\text {pro }}(0,00 \leq 0,05)$. Meaning a rejection of $\mathrm{H}_{0}$ which indicates that there is a cost impact of production on industrial production at home industry of sambel pecel at Madiun city. Also obtained regression coefficients ( $t$ test) with $t_{\text {hit }} 29.581 t_{t a b} 1.693$ on the other hand Sig $_{\text {hit }} 0.00$ and Sig $_{\text {pro }} 0.05$. This means that the $t_{\text {hit }} \geq t_{\text {tab }}(29.581 \geq 1.693)$ or $\operatorname{Sig}_{\text {hit }} \leq \operatorname{Sig}_{\text {pro }}(0,00 \leq 0,05)$. Results $\mathrm{R}^{2}$ of $96.5 \%$. Showed that $96.5 \%$ of the variable cost of production is affected production, while the remaining $3.5 \%$ is influenced by other factors.
\end{abstract}

Keywords: Production Cost, Production Result 


\section{Pendahuluan}

Pembangunan ekonomi diarahkan kepada terwujudnya perekonomian nasional yang mandiri dan handal berdasarkan demokrasi ekonomi untuk meningkatkan kemakmuran ekonomi secara selaras, adil dan merata. Pembangunan ekonomi merupakan salah satu pembangunan guna meningkatkan taraf hidup kesejahteraan rakyat. Sasarannya adalah untuk mencapai keseimbangan antara bidang pertanian dan bidang industri serta terpenuhinya kebutuhan pokok rakyat.

Krisis ekonomi sejak tahun 1997 yang lalu secara nyata telah menyebabkan jatuhnya ekonomi nasional khususnya usaha-usaha skala besar pada semua sektor termasuk industri, jasa dan perdagangan. Akhirnya tidak sedikit perusahaan yang menutup usahanya. Sektor Usaha Kecil dan Menengah (UKM) pada kenyataannya mampu menunjukkan kinerja yang lebih tangguh dalam menghadapi masa krisis. Pada masa-masa krisis perekonomian yang telah terjadi beberapa tahun yang lalu, Indonesia jusru terselamatkan oleh masih stabilnya kegiatan usaha mikro, kecil dan menengah. Ini berarti segmen usaha tersebut telah teruji sangat kenyal dan adaptif terhadap berbagai perubahan bahkan saat krisis ekonomi sekalipun. Usaha mikro dan kecil ini merupakan bagian dari perekonomian kerakyatan karena jumlah sektor primernya yang cukup dominan. Sehingga bisa dikatakan bahwa usaha mikro, dan kecil mempunyai andil besar dalam perekonomian nasional.

Home industri yang merupakan salah satu Perusahaan perseorangan adalah Perusahaan yang dimiliki oleh seorang yang langsung memimpin perusahaan tersebut. Pemiliknya memiliki tanggung jawab yang tidak terbatas atas utang-utang perusahaan dan berkuasa penuh atas pengelolaan dan pengendalian perusahaan. Tanggung jawab tidak terbatas artinya bahwa orang tersebut (pemilik) bertanggung jawab atas kewajiban atau utang-utangnya dengan mengorbankan modal yang dimasukkannya ke dalam perusahaan tersebut dan dengan seluruh milik pribadinya.

Pemilik-pemilik Home industri menjalankan kegiatannya untuk mencari hasil dan keuntungan yang maksimum, keuntungan yang maksimum hanya akan didapat apabila pemilik atau pemimpin Home industri membuat pilihan yang tepat terhadap jenis barang atau jasa yang akan dijualnya, dan jenis-jenis serta jumlah faktor-faktor produksi yang akan digunakannya. Dalam penjualan barang, para pengusaha dapat menentukan tingkat produksi yang dapat memberi keuntungan paling banyak kepada kegiatannya.

Peningkatan produksi tidak dapat lepas dari biaya produksi, karena biaya merupakan seluruh sumber daya yang digunakan untuk menghasilkan dan memperoleh suatu barang atau jasa (Wilson Bangun 2007: 89). Sehingga untuk mencapai hasil produksi yang maksimal dibutuhkan ketersediaan input atau faktor-faktor produksi yang cukup. Biaya produksi akan selalu muncul dalam setiap kegiatan ekonomi, dimana usahanya selalu berkaitan dengan diperlukannya input (faktor produksi) yang digunakan dalam setiap kegiatan produksi tersebut. 
Pemahaman mengenai biaya produksi sangat penting karena tujuannya untuk mencapai laba yang maksimum, oleh sebab itu pemilik harus memahami antara penerimaan dan biaya produksi dalam menghasilkan barang, perbedaan penerimaan dan biaya produksi itulah yang disebut dengan laba perusahaan.

Sambel pecel merupakan produk dari salah satu Home industri yang juga merupakan produk khas Madiun. Di Madiun, industri sambel pecel tumbuh subur sebagai industri rumah tangga. Para produsen melihat dari semua sisi dalam menjalankan usaha produksi sambel pecel. Pertama, produsen mempertimbangkan bahwa sambel pecel merupakan makanan khas madiun yang sudah diproduksi turun-temurun. Kedua, dilihat dari bahan baku pembuatan sambel pecel sangat mudah didapat sehingga mudah untuk memproduksi sambel pecel. Ketiga, dalam pemasaran sambel pecel tidaklah sulit, karena sambel pecel Madiun sudah dikenal kekhasannya. Namun, pada dasarnya apapun usaha dalam berproduksi haruslah diperhitungkan biaya (input) dan seberapa barang yang dihasilkan (output) dengan tujuan untuk mencapai hasil yang diinginkan.

Dalam menjalankan proses produksinya, para produsen sering mengalami berbagai kendala diantaranya, naiknya harga bahan bakar minyak (BBM) naiknya harga cabe, naiknya harga gula, harga kacang mentah. Dan hal itu semua berakibat pada naiknya biaya produksi yang berdampak pada berkurangnya harga jual dan pada akhirnya kondisi inilah yang menyebabkan jumlah hasil produksi menurun.

Produksi merupakan transformasi atau penggunaan bahan faktor produksi menjadi barang produksi, atau suatu proses dimana masukan (input) diubah menjadi luaran (output). (M. Suparmoko 2011: 77). Salah satu kriteria Suatu proses produksi dikatakan berhasil jika suatu proses produksi itu menghasilkan barang- barang yang dapat dijual. sesuai pendapat Sri joko (2004: 99) Hasil Produksi merupakan tingkat produksi yang dinyatakan dalam jumlah unit barang yang diproduksikan dan dijual.

Hasil produksi optimal dapat dicapai apabila ada pengorganisasian penggunaan input sebaik mungkin, ini dapat dilihat dari berapa besar sumbangan seluruh input terhadap produksi. Dalam bukunya Sadono Sukirno (2002: 192) disebutkan bahwa tingkat produksi suatu barang tergantung kepada jumlah modal, jumlah tenaga kerja, jumlah kekayaan alam dan tingkat teknologi yang digunakan.

\section{Hasil Produksi}

Salah satu kriteria suatu proses produksi dikatakan berhasil jika suatu proses produksi itu menghasilkan barang-barang yang dapat dijual. Sesuai pendapat Sri joko (2004: 99) Hasil produksi merupakan tingkat produksi yang dinyatakan dalam jumlah unit barang yang diproduksikan dan dijual. dalam hal ini diasumsikan bahwa, barang-barang yang sudah diproduksi dapat dijual.

Sedangkan Menurut Soediyono Reksoprayitno (2000: 233) Hasil Produksi (Output) merupakan jumlah produksi yang dihasilkan dalam jangka 
waktu tertentu sebagai pemakaian sejumlah faktor-faktor produksi dalam proses produksi untuk jangka yang sama.

Dari bebrapa definisi diatas dapat disimpulkan bahwa hasil produksi adalah total barang yang dihasilkan oleh unit usaha atau perusahaan setelah pemakaian faktor-faktor produksi tertentu. Hasil produksi merupakan keluaran (output) yang diperoleh dari pengelolaan input produksi (sarana produksi atau biasa disebut masukan) dari suatu usaha.

Dalam Hal ini yang dimaksud dengan hasil produksi adalah semua keluaran yang diperoleh atau sejumlah hasil yang diperoleh dari produksi sambel pecel setelah dilakukan pengolahan input produksi dalam satu kali proses produksi.

Satu kali proses produksi disini diartikan sebagai waktu yang diperlukan dalam berproduksi yang diukur sejak bahan baku berupa kacang mentah melalui proses penggorengan dalam hal ini kacang mentah di sangrai, peracikan yang mengkombinasi berbagai jenis bumbu lain, penggilingingan hingga sambel pecel siap dikonsumsi dan dijual. Proses ini rata-rata menghabiskan waktu 3-8 jam, atau sesuai dengan jumlah produksinya.

Biaya produksi dapat didefinisikan sebagai semua pengeluaran yang dilakukan oleh perusahaan untuk memperoleh faktor-faktor produksi dan bahan-bahan mentah yang akan digunakan untuk menciptakan barang-barang yang diproduksikan perusahaan tersebut (Sadono Sukirno, 2002: 205).

Suherman Rosyid (2001: 365) mendefinisikan bahwa biaya produksi merupakan biaya yang harus dikeluarkan oleh pengusaha untuk dapat menghasilkan output.

Sedangkan Menurut Suparmoko (2011: 113) biaya produksi adalah hasil kali antar masukan yang dipakai dalam perusahaan dengan harganya masing-masing.

Biaya produksi yang dikeluarkan oleh perusahaan dapat dibedakan menjadi dua jenis yaitu biaya eksplisit yaitu pengeluaran-pengeluaran perusahaan yang berupa pembayaran dengan uang untuk mendapatkan faktorfaktor produksi dan bahan mentah yang dibutuhkan biaya tersembunyi yaitu taksiran pengeluaran terhadap faktor-faktor produksi yang dimiliki oleh perusahaan itu sendiri. Yang termasuk biaya tersembunyi yaitu pembayaran untuk keahlian keusahawanan produsen tersebut, modalnya sendiri yang digunakan dalam perusahaan, dan bangunan perusahaan yang dimiliki (sadono sukirno, 2010: 208)

Dalam perekonomian indonesia, sektor industri dan kecil memegang peranan yang sangat penting terutama jika dikaitkan dengan jumlah tenaga kerja yang mampu diserap oleh industri dan usaha kecil. Industri dan Usaha kecil ini selain memiliki arti strategis bagi pembangunan, juga sebagi upaya untuk memeratakan hasil-hasil pembangunan yang telah tercapai.

Menurut Basu swasta (2002: 11) Industri merupakan suatu kelompok perusahaan yang memproduksi kelompok barang yang sama, untuk pasar yang sama pula.

Berdasarkan UU No. 9/1995 (Dalam Pandji Anoraga dan Djoko Sudantoko, 2002: 225) tentang usaha kecil, yang dimaksud dengan usaha 
kecil adalah kegiatan ekonomi rakyat yang berskala kecil dalam memenuhi kriteria kekayaan bersih atau hasil penjualan tahunan seperti kepemilikan sebagai mana diatur dalam undang-undang.

Untuk mendapatkan berbagai faktor-faktor produksi tersebut diperlukan biaya. Biaya-biaya ini dikeluarkan untuk menghasilkan produk yang dapat mendatangkan manfaat dimasa datang yang biasanya berupa laba maupun sisa hasil usaha.

Demikian pula Home industri sambel pecel yang ada dikota Madiun, para produsen memerlukan biaya produksi yang berupa biaya bahan baku berupa kacang mentah, cabe, bawang jeruk purut ataupun daun jeruk purut, serta biaya tenaga kerja untuk menjalankan usahanya, hingga akhirrnya mereka dapat menikmati keuntungan dari proses produksi.

\section{METODE PENELITIAN}

Tempat diadakannya penelitian ini adalah dikota Madiun. Secara administratif, Pemerintah Kota Madiun membawahi 3 (tiga) kecamatan. Adapun kecamatan-kecamatan tersebut antara lain seperti : Kecamatan Mangunharjo, Kecamatan Taman dan Kecamatan Kartoharjo (Pemerintah kota Madiun 2004: 35). Di kota Madiun banyak terdapat home industri yang memproduksi sambel pecel yang juga dikenal sebagai makanan khas Madiun.

Penelitian tentang pengaruh biaya produksi terhadap hasil produksi sambel pecel di kota Madiun, dilaksanakan selama 4 bulan, yaitu bulan Februari sampai dengan Mei 2013.

Penelitian deskriptif ini bertujuan untuk menggambarkan/memecahkan masalah secara sistematis, faktual, dan akurat mengenai fakta-fakta dan sifatsifat populasi atau daerah tertentu, (Usman Rianse dan Abdi, 2012: 30).

Metode yang digunakan dalam penelitian ini adalah metode penelitian kuantitatif. Sugiyono (2007: 8) menyatakan metode kuantitatif adalah metode penelitian yang berlandaskan pada filsafat positivisme, digunakan untuk meneliti pada populasi atau sampel tertentu, pengumpulan data menggunakan instrumen penelitian, analisis data bersifat kuantitatif/statistik, dengan tujuan untuk menguji hipotesis yang telah ditetapkan. Sedangkan Algifari (2003: 9) mengatakan data kuantitatif adalah nilai data yang dinyatakan dalam skala numerik (angka) yang diolah dengan metode statistik.

Dalam penelitian ini terdapat 2 variabel yaitu:

1. Variabel Bebas (variabel independent).

Dalam penelitian ini variable bebasnya adalah Biaya produksi (X)

2. Variabel Terikat (Variabel Dependent)

Dalam penelitian ini variabel terikatnya adalah Hasil produksi (Y)

Populasi dalam penelitian ini adalah seluruh home industri sambel pecel yang ada di kota Madiun. Menurut dinas perindustrian dan perdagangan kota Madiun, tercatat terdapat 34 home industri sambel pecel di wilayah kota Madiun, Sehigga yang menjadi populasi dalam penelitian ini sebanyak 35 home industri Sambel pecel di kota Madiun.

Dalam penelitian ini yang menjadi sample adalah semua home industri sambel pecel kota Madiun yang berjumlah 35 home industri. Sesuai pendapat 
Suharsimi Arikunto (2002: 112) jika jumlah populasi penelitian kurang dari 100 maka diambil semua. Dalam hal ini peneliti mengambil semua populasi sebagai sample sehingga penelitian ini adalah penelitian populasi.

Teknik pengambilan sampel dalam penelitian ini adalah Sampling jenuh, yaitu teknik penentuan sampel jika semua anggota populasi digunakan sebagai sample (Sugiyono, 2006: 85)

Data-data yang diperlukan untuk penelitian dikumpulkan dengan teknik pengumpulan data. Dalam penelitian ini teknik pengumpulan data yang digunakan adalah:

1. Wawancara

Wawancara digunakan oleh peneliti untuk menilai keadaan seseorang, lembaga, ataupun perusahaan. Dalam penelitian ini wawancara digunakan untuk mengetahui jumlah masing-masing dari biaya produksi yang diperlukan dan hasil produksi yang diperoleh dalam satu kali produksi.

2. Dokumentasi

Dokumentasi dibgunakan untuk mendapatkan informasi data tambahan yang diperlukan dan yang berhubungan dengan penelitian.

Dalam penelitian ini instrumen yang digunakan adalah Pedoman wawancara (inteview guide) yaitu wawancara dengan para subyek yang diteliti dengan menggunakan pedoman wawancara. Dalam hal ini berupa pertanyaan yang ditujukan kepada setiap pimpinan atau pemilik home industri sambel pecel di kota Madiun.

Analisis data dalam penelitian ini menggunakan program SPSS (Statistical Product and Service Solution) for windows versi 16.0. Dalam penelitian ini analisis yang digunakan untuk mencari pengaruh antara biaya produksi terhadap hasil produksi digunakan regresi linier.

Moehar Daniel (2003: 155) berpendapat bahwa "metode regresi digunakan untuk menguji hubungan sekaligus pengaruh dari (independent variabel) variabel bebas terhadap (dependent variabel) variabel terikat.

\section{Hasil Penelitian}

\section{Variabel Biaya Produksi}

variabel hasil produksi, dengan jumlah N 34 Home industri sambel pecel dalam statistik deskriptifnya sebagai berikut: (a) Nilai jumlah total skor sebesar 729; (b) Nilai Mean sebesar 21.44; (c) Nilai Median sebesar 19.00; (d)Nilai Modus sebesar 16; (e) Nilai standar deviasi sebesar 6.920; (f) Nilai Minimum sebesar 14; (g) Nilai Maximum sebesar 43.

Dari hasil analisis deskriptif tersebut, diperoleh hasil 14 atau $41 \%$ home industri sambel pecel di kota Madiun mempunyai hasil produksi yang tinggi karena berada di atas mean atau hasil produksi rata-rata. Sedangkan sebanyak 20 home industri atau 59\% home industri mempunyai hasil produksi yang rendah karena berada dibawah mean atau hasil produksi rata-rata.

\section{Variabel Hasil Produksi}


variabel hasil produksi, dengan jumlah N 34 Home industri sambel pecel dalam statistik deskriptifnya sebagai berikut: (a) Nilai jumlah total skor sebesar 729; (b) Nilai Mean sebesar 21.44; (c) Nilai Median sebesar 19.00; (d)Nilai Modus sebesar 16; (e) Nilai standar deviasi sebesar 6.920; (f) Nilai Minimum sebesar 14; (g) Nilai Maximum sebesar 43.

Dari hasil analisis deskriptif tersebut, diperoleh hasil 14 atau $41 \%$ home industri sambel pecel di kota Madiun mempunyai hasil produksi yang tinggi karena berada di atas mean atau hasil produksi rata-rata. Sedangkan sebanyak 20 home industri atau 59\% home industri mempunyai hasil produksi yang rendah karena berada dibawah mean atau hasil produksi rata-rata.

\section{Hasil Uji Korelasi}

Hasil uji korelasi didapat nilai $r_{\text {hit }}$ sebesar 0,982 sedangkan $r_{\text {tab }}$ sebesar 0,339. Dilain pihak nilai $\mathrm{Sig}_{\text {hit }}$ sebesar 0,000 dan $\operatorname{sig}_{\text {prob }}$ sebesar 0,05. Hal ini berarti nilai $r_{\text {hit }} \geq r_{\text {tab }}(0,982 \geq 0,339)$ atau $\operatorname{Sig}_{\text {hit }} \leq \operatorname{Sig}_{\text {pro }}(0,000 \leq 0,05)$. Dapat diartikan bahwa ada hubungan antara biaya produksi dengan hasil produksi di Home industri sambel pecel di kota Madiun.

Dengan demikian diperoleh pula nilai untuk $\mathrm{R}^{2}$.Nilai $\mathrm{R}^{2}$ adalah sebesar 96,5\%. Hal ini dapat diartikan bahwa sebesar 96,5\% variabel hasil produksi dipengaruhi oleh biaya produksi sedangkan sisanya 3,5\% dipengaruhi oleh faktor yang tidak diteliti dalam penelitian ini.

\section{Uji Fisher}

Dari hasil uji fisher dapat diketahui nilai $\mathrm{F}_{\text {hit }}$ sebesar 875,064 sedangkan nilai $\mathrm{F}_{\text {tabel }}$ sebesar 4,149. Dilain pihak nilai $\mathrm{Sig}_{\text {hit }}$ sebesar 0,000 dan $\mathrm{Sig}_{\text {Pro }}$ sebesar 0,05 . Hal ini berarti bahwa nilai $F_{\text {hit }} \geq F_{\text {tab }}(875.064 \geq 4,149)$ Sig $_{\text {hit }} \leq$ $\operatorname{Sig}_{\text {pro }}(0,000 \leq 0,05)$. Hal ini dapat dikatakan bahwa $\mathrm{H}_{0}$ ditolak dan $\mathrm{Ha}$ diterima, artinya ada pengaruh biaya produksi terhadap hasil produksi pada home industri sambel pecel di kota Madiun.

\section{Uji t}

\begin{tabular}{|c|c|c|c|c|c|}
\hline \multicolumn{6}{|c|}{ Coefficients $^{a}$} \\
\hline \multirow[b]{2}{*}{ Model } & \multicolumn{2}{|c|}{ Unstandardized Cefficients } & \multirow{2}{*}{$\begin{array}{c}\text { Standardized } \\
\text { Coefficients } \\
\text { Beta }\end{array}$} & \multirow[b]{2}{*}{$\mathrm{t}$} & \multirow[b]{2}{*}{ Sig. } \\
\hline & $B$ & Std. Error & & & \\
\hline 1 (Constant) & .584 & .741 & & .789 & .436 \\
\hline Biayaproduksi & $4.435 E-5$ & .000 & .982 & 29.581 & .000 \\
\hline
\end{tabular}

Dalam koefisien regresi atau uji $t$ diperoleh nilai $t_{\text {hit }}$ sebesar 29,581 $t_{\text {tab }}$ sebesar 1,693 atau nilai Sig hit $_{\text {sebesar 0,000 dan sig }}$ pro sebesar 0,05. Hal ini berarti bahwa nilai $t_{\text {hit }} \geq t_{\text {tab }}(29,581 \geq 1.693) \operatorname{Sig}_{\text {hit }} \leq \operatorname{Sig}_{\text {pro }}(0,000 \leq 0,05)$. Hal ini dapat dikatakan bahwa $\mathrm{H}_{0}$ ditolak, artinya ada beda pengaruh biaya 
produksi terhadap hasil produksi pada Home industri sambel pecel di kota Madiun

Lebih lanjut apabila dilihat dalam persamaan garis regresi diperoleh persamaan nilai $\mathrm{Y}=0,584+4,43 \mathrm{X}$ dari persamaan garis regresi tersebut dapat dilihat jika biaya produksi meningkat sebanyak $1 \%$, hasil produksi akan meningkat pula sebesar $4,43 \%$ sedangkan faktor lain tetap. Koefisien bernilai positif artinya terjadi hubungan positif antara biaya produksi dengan hasil produksi, semakin tinggi biaya produksi semakin meningkat hasil produksi.

\section{Simpulan Hasil Analisis}

Atas dasar hasil pengujian hipotesis dapat diambil simpulan sebagai berikut:

\section{Simpulan Uji Korelasi}

Dalam uji korelasi diperoleh nilai $r_{\text {hit }}$ sebesar 0,982 sedangkan $r_{\text {tab }}$ sebesar 0,339. Dilain pihak nilai $\mathrm{Sig}_{\text {hit }}$ sebesar 0,000 dan $\operatorname{sig}_{\text {pro }}$ sebesar 0,05. Hal ini berarti nilai $r_{\text {hit }} \geq r_{\text {tab }}(0,982 \geq 0,339)$ atau $\operatorname{Sig}_{\text {hit }} \leq \operatorname{Sig}_{\text {pro }}(0,000 \leq 0,05)$. Dapat diartikan bahwa ada hubungan antara biaya produksi dengan hasil produksi pada Home industri sambel pecel di kota Madiun.

Diketahui pula nilai $\mathrm{R}^{2}$ sebesar 0,965 dapat dikatakan bahwa sebesar 96,5\% variabel terikat (Y) dalam penelitian ini hasil produksi dipengaruhi oleh biaya produksi sebagai variabel bebas (X), sisanya 3,5\% dipengaruhi oleh faktor lain.

Dapat disimpulkan $\mathrm{H}_{0}$ artinya ada hubungan antara biaya produksi dengan hasil produksi pada home industri sambel pecel di kota Madiun.

\section{Simpulan Uji Fisher}

Hasil dari pengujian fisher dapat diperoleh nilai $F_{h i t}$ adalah 875,064 sedangkan $F_{\text {tab }}$ sebesar 4,149 dilain pihak besarnya Sighit adalah 0,000 sedangkan $\operatorname{Sig}_{\text {pro }}$ 0,05. Hal ini berarti bahwa nilai $F_{\text {hit }} \geq F_{\text {tab }}(875.064 \geq$ 4,149) $\operatorname{Sig}_{\text {hit }} \leq \operatorname{Sig}_{\text {pro }}(0,000 \leq 0,05)$. Hal ini dapat dikatakan bahwa $\mathrm{H}_{0}$ ditolak, artinya ada pengaruh biaya produksi terhadap hasil produksi pada Home industri sambel pecel di kota Madiun.

\section{Simpulan Uji t}

Berdasarkan hasil uji $t$ diperoleh nilai $t_{\text {hit }}$ sebesar 29,581 $t_{\text {tab }}$ sebesar 1,693 atau nilai $\mathrm{Sig}_{\text {hit }}$ sebesar 0,000 dan $\mathrm{Sig}_{\text {pro }}$ sebesar 0,05. Hal ini berarti bahwa nilai $t_{\text {hit }} \geq t_{\text {tab }}(29,581 \geq 1,693) \operatorname{Sig}_{\text {hit }} \leq \operatorname{Sig}_{\text {pro }}(0,00 \leq 0,05)$. Hal ini dapat dikatakan bahwa $\mathrm{H}_{0}$ ditolak, artinya ada beda pengaruh biaya produksi terhadap hasil produksi pada Home industri sambel pecel di kota Madiun.

Dari hasil pengujian yang telah dilakukan diperoleh persamaan garis regresi sebagai berikut $\mathrm{Y}=0,584+4,43 \mathrm{X}$ dari persamaan garis regresi tersebut dapat dilihat jika biaya produksi meningkat sebanyak $1 \%$, hasil produksi akan meningkat pula sebesar $4,43 \%$ sedangkan faktor lain tetap. 
Dari hasil penelitian menunjukkan bahwa Biaya produksi mempunyai hubungan sekaligus pengaruh terhadap hasil produksi sambel pecel di kota Madiun. Artinya apabila produsen meningkatkan biaya produksi sambel pecel, dapat pula terjadi peningkatkan hasil produksi yang diperoleh. Dengan adanya biaya yang tersedia maka para produsen sambel pecel akan memperoleh hasil yang diinginkan.

Besar kecilnya tingkat produksi suatu barang tergantung pada jumlah modal, tenaga kerja, kekayaan alam dan tingkat teknologi yang digunakan (Sadono sukirno, 2002: 192). Dalam hal ini yang dimaksud hasil produksi adalah semua hasil yang diperoleh dari proses produksi setelah dilakukan pengolahan input yaitu berupa bahan baku yang digunakan dan untuk memperoleh bahan baku tersebut diperlukan biaya. Ini berarti tingkat produksi suatu barang tergantung dari jumlah biaya yang dimiliki.

\section{Pembahasan Uji Korelasi}

Untuk uji korelasi diperoleh nilai $r$ hit sebesar 0,982 sedangkan $r_{\text {tab }}$

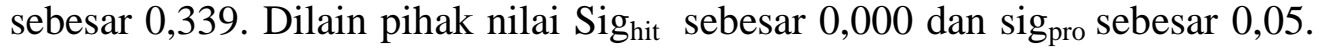
Hal ini berarti nilai $r_{\text {hit }} \geq r_{\text {tabel }}(0,982 \geq 0,339)$ atau $\operatorname{Sig}_{\text {hit }} \leq \operatorname{Sig}_{\text {pro }}(0,000 \leq$ $0,05)$. Dapat diartikan bahwa ada hubungan antara biaya produksi dengan hasil produksi pada home industri sambel pecel kota Madiun.

Selain itu diperoleh nilai $\mathrm{R}^{2}$ sebesar 0,965 dapat dikatakan bahwa sebesar 96,5\% variabel terikat (Y) dalam penelitian ini hasil produksi dipengaruhi oleh biaya produksi sebagai variabel bebas $(\mathrm{X})$, sisanya 3,5\% dipengaruhi oleh faktor lain yang tidak diteliti dalam penelitian ini.

\section{Pembahasan Uji Fisher}

Berdasarkan pengujian fisher dapat diperoleh nilai $F_{\text {hit }}$ adalah 875,064 sedangkan $\mathrm{F}_{\text {tab }}$ sebesar 4,149 dilain pihak besarnya Sighit adalah 0,000 sedangkan $\operatorname{Sig}_{\text {prob }}$ 0,05. Hal ini berarti bahwa nilai $\mathrm{F}_{\text {hit }} \geq \mathrm{F}_{\text {tab }}(875.064 \geq$ 4,149) $\operatorname{Sig}_{\text {hit }} \leq \operatorname{Sig}_{\text {pro }}(0,000 \leq 0,05)$.

Hal ini dapat dikatakan bahwa $\mathrm{H}_{0}$ ditolak, artinya ada pengaruh biaya produksi terhadap hasil produksi di Home industri sambel pecel di Kota Madiun.

\section{Pembahasan Uji t}

Dapat dilihat hasil persamaan garis regresi $\mathrm{Y}=0,584+4,43 \mathrm{X}$ sedangkan untuk uji $\mathrm{t}$ diperoleh nilai $\mathrm{t}_{\text {hit }} 29,581 \mathrm{t}_{\text {tab }}$ sebesar 1,693 atau nilai $\mathrm{Sig}_{\text {hit }}$ sebesar 0,000 dan $\mathrm{Sig}_{\text {pro }}$ sebesar 0,05. Hal ini berarti bahwa nilai $\mathrm{t}_{\text {hit }} \geq \mathrm{t}_{\mathrm{tab}}(29,581 \geq$ 1,693) $\operatorname{Sig}_{\text {hit }} \leq \operatorname{Sig}_{\text {pro }}(0,000 \leq 0,05)$. Hal ini dapat dikatakan bahwa $\mathrm{H}_{0}$ ditolak, artinya ada beda pengaruh biaya produksi terhadap hasil produksi pada home industri sambel pecel di kota Madiun.

Dari hasil penelitian menunjukkan bahwa biaya produksi mempunyai hubungan sekaligus pengaruh terhadap hasil produksi sambel pecel di kota Madiun. Artinya apabila produsen meningkatkan biaya produksi sambel pecel, dapat pula terjadi peningkatkan hasil produksi yang diperoleh. Dengan 
adanya biaya yang tersedia maka para produsen sambel pecel akan memperoleh hasil yang diinginkan.

Besar kecilnya tingkat produksi suatu barang tergantung pada jumlah modal, tenaga kerja, kekayaan alam dan tingkat teknologi yang digunakan (Sadono sukirno, 2002: 192). Dalam hal ini yang dimaksud hasil produksi adalah semua hasil yang diperoleh dari proses produksi setelah dilakukan pengolahan input yaitu berupa bahan baku yang digunakan dan untuk memperoleh bahan baku tersebut diperlukan biaya. Ini berarti tingkat produksi suatu barang tergantung dari jumlah biaya yang dimiliki.

\section{Penutup \\ Simpulan}

Berdasarkan hasil penelitian analisis data dan pembahasan dapat disimpulkan sebagai berikut:

1. Biaya produksi pada home industri sambel pecel di kota Madiun, berdasarkan hasil wawancara dari 34 home industri, diperoleh hasil 12 home industri atau 35\% home industri sambel pecel mempunyai biaya produksi yang tinggi karena berada diatas mean atau biaya rata-rata. Sedangkan sebanyak 22 home industri atau $65 \%$ home industri sambel pecel mempunyai biaya produksi yang rendah karena berada dibawah biaya rata-rata. Hasil analisis biaya produksi berdasarkan statistik deskriptif diperoleh hasil sebagai berikut: (a) Nilai total skor sebesar 15988000: (b) Nilai mean sebesar 470235; (c) Nilai median sebesar 426500,00; (d) Nilai modus sebesar 300000; (e) Nilai standar deviasi sebesar 153244.320; (f) Nilai minimum sebesar 295000; (g) Nilai maksimum sebesar 8400000 .

2. Hasil produksi sambel pecel pada home industri sambel pecel di kota Madiun, Berdasarkan hasil wawancara dari 34 home industri sambel pecel di kota Madiun, diperoleh hasil 14 home industri atau $41 \%$ home industri sambel pecel mempunyai hasil produksi yang tinggi karena berada diatas mean atau hasil produksi rata-rata. Sedangkan sebanyak 20 home industri atau 59\% home industri mempunyai hasil produksi yang rendah karena berada di bawah mean atau hasil produksi rata-rata. Hasil analisis hasil produksi berdasarkan satistik deskriptif diperoleh hasil sebagai berikut: (a) Nilai total skor sebesar729; (b) Nilai mean sebesar 21,44; (c) Nilai median sebesar 19.00; (d) Nilai modus sebesar 16; (e) Nilai standar deviasi sebesar 6.920; (f) Nilai minimum sebesar 14; (g) Nilai maksimum sebesar 43.

3. Ada pengaruh biaya produksi terhadap hasil produksi pada home industri sambel pecel di kota Madiun, Ini berarti $\mathrm{H}_{0}$ ditolak dan $\mathrm{Ha}$ diterima. Hal ini berdasarkan analisis data diperoleh nilai korelasi $r_{\text {hitung }}$ sebesar $0,982 \geq$ $\mathrm{r}_{\text {tabel }}$ 0,339 atau nilai $\mathrm{Sig}_{\text {hit }}$ sebesar $0,000 \leq$ Sig $_{\text {pro }}$ sebesar 0,05.Untuk uji F diperoleh nilai $F_{\text {hitung }}$ sebesar 875,064 $\geq F_{\text {tabel }}$ sebesar 4,149 atau nilai Sig hit sebesar $0,000 \leq \mathrm{Sig}_{\text {pro }}$ sebesar 0,05. Dan uji t, nilai $\mathrm{t}_{\text {hitung }}$ sebesar 29,581 $\geq$ $\mathrm{t}_{\text {tabel }}$ sebesar 1,693 atau nilai $\mathrm{Si}_{\text {ghit }}$ sebesar $0,00 \leq \mathrm{Sig}_{\text {tab }}$ sebesar 0,05 . Selain itu perolehan nilai $\mathrm{R}^{2}$ sebesar 0.965 . Hal ini dapat diartikan bahwa sebesar 
96,5\% variabel hasil produksi dipengaruhi oleh biaya produksi, sedangkan $3,5 \%$ dipengaruhi oleh faktor lain.

Saran

Biaya produksi besar pengaruhnya terhadap hasil produksi yang diperoleh, oleh karena itu, jika perusahaan ingin memperoleh hasil produksi yang diinginkan maka produsen harus menjaga kestabilan biaya yang dimiliki agar proses produksi dapat berlanjut dan dapat memperoleh hasil yang maksimal.

\section{DAFTAR PUSTAKA}

Algifari.2003.Statistik Induktif. Yogyakarta: Akademi manajemen Perusahaan YKPN.

A Rainborn Cecilya .2011.Akuntansi Biaya.Jakarta: Salemba Empat.

Basu Swasta. 2002. Pengantar Bisnis modern. Yogyakarta : Liberty.

Daryanto. 2012. Sari Kuliah Manajemen Produksi. Bandung : satu Nusa.

Departement Pendidikan. 2005. Ilmu Pengetahuan Sosial-Ekonomi. Jakarta.

Duwi Priyatno.2010. Teknik Mudah Dan Cepat Melakukan analisi data penelitian SPSS dan tanya jawab Ujian pendadaran.Yogyakarta: gava Media.

Husein Umar.2011. Metode Penelitian Untuk Skripsi dan Tesis Bisnis.jakarta: Rajawali Pers.

Julinsyah Noor.2012.Metodologi Penelitian. Jakarta: Kencana Prenada Group.

Moehar Daniel.2003. Metode Penelitian Sosial Ekonomi. jakarta: PT Bumi Aksara.

M. Suparmoko. 2011. Teori Ekonomi Mikro. Yogyakarta : BPFE.

Mulyadi. 2007. Akuntansi Biaya.Yogyakarta: Sekolah tinggi Ilmu Manajemen YKPN.

Pandji anoraga. 2002. Manajemen Bisnis. Jakarata: Rhineka Cipta.

Pemerintah Kota Madiun.2004. Merangkul Mutiara di Kota Madiun.Madiun 
Rayburn L Gayle.1999. Akuntansi Biaya. Jakarta : Erlangga.

Sadono Sukirno.2002. Pengantar teori Mikro Ekonomi. Jakarta: PT RajaGrafindo Persada.

Soediyono Reksprayitno.2000. Pengantar ekonomi Mikro edisi Millenium. Yogyakarta: BPFE.

Sofyan Siregar.2011. Statistik Deskriptif untuk Penelitian. Jakarta : Rajawali pers

Sugiyono. 2007.Statistika Untuk Penelitian. Bandung: CV Alfabeta.

Suharsimi Arikunto.2002. Prosedur Penelitian. Jakarta: Rhineka Cipta.

Suherman Rosyid.2011. Pengantar Teori ekonomi Mikro dan Makro. Jakarta: PT Raja Grafindo Persada.

Sukanto Reksohadiprojo. 1997.Manajemen Produki Dan Operasi. Yogyakarta : BPFE.

Sukaria Sinulingga.2009.Perencanaan dan Pengendalian Produksi.Yogyakarta : Graha Ilmu.

Sukardi. 2003. Metodologi Penelitian Pendidikan.Jakarta: Bumi Aksara.

Srijoko.2004. Manajemen Produksi dan Operasi.Malang; UMM.

Wilson Bangun. 2007. Teori Ekonomi Mikro. Bandung : Refika Aditama 